\title{
ASSOCIATED ECONOMY - WIDE EFFECTS OF TRANSPORT AND LOGISTICS CLUSTERS
}

\author{
Noleen PISA* \\ University of Johannesburg; College of Business and Economics; Johannesburg Business School \\ Department of Transport and Supply Chain Management, e-mail: noleenp@uj.ac.za
}

Citation: Pisa, N. (2019). ASSOCIATED ECONOMY - WIDE EFFECTS OF TRANSPORT AND LOGISTICS CLUSTERS. GeoJournal of Tourism and Geosites, 27(4), 1212-1226. https://doi.org/10.30892/gtg.27408-427

\begin{abstract}
Regional competitiveness can be improved by providing value-added services, such as transport and logistics services to both the local and global supply chains. Transport and logistics clusters have been shown to reduce trade transactions and to improve the efficiency of both local and international transactions. The aim of this study was to identify the sectors that comprise the transport and logistics cluster and to determine the cluster's associated economywide effects. Using a cross-sectional study design, location-specific competitive advantages and economic multipliers associated with the clustering of transport and logistics companies were computed for the North-West Province in South Africa. Findings illustrate that the transport and logistics cluster comprises seven sectors that associate positively with upstream and downstream multipliers in various sectors within the region. Additionally, the sectors in the cluster are relatively integrated and have high interlinkages. The cluster has potential for higher levels of integration once the cluster is strengthened. In the context of South Africa, this implies that transport and logistics cluster optimisation has a knock on effect on various industries including tourism as shown elsewhere. This study offers a unique econometric approach to identify and quantify the effects of transport and logistics clusters on regional competitiveness and provides practitioners and policy makers with insights into alternative strategies to enhance regional competitiveness and growth.
\end{abstract}

Key words: transport and logistics clusters, economy-wide effects, regional competitiveness

\section{INTRODUCTION}

Various factors contribute to country-level competitiveness. Substantial evidence exists on the successes of various strategies to attain global competitiveness. The success of East Asian economies such as Hong Kong, Taiwan and Korea, after World War II, is attributed to the promotion of trade (Balassa, 1978). Exporting promotes technological advancements leading to the development of technological capabilities and production

\footnotetext{
* Corresponding author
} 
efficiency as a result of the efficient allocation of resources (Awokuse, 2008). The manufacturing-led growth strategies propelled the economies of first world countries such as the US, UK and, more recently, China. Other notable strategies are service innovation in the form of the provision of value-added services that improve the service offering of physical products as well as cluster formation to enhance cooperation and competitiveness (Sheffi, 2010; 2013). Regional competitiveness can be improved by providing high value-added services, such as transport and logistics services to both the local and global supply chains (Ahmad et al., 2017). Logistics is derived demand for transport and warehousing resulting from other activities such as the need to transport raw materials to production factories and the need for storage and distribution of finished goods to retail locations (Prause, 2010). Logistics clusters are geographic concentrations of transport and logistics service providers including transport carriers, warehouses, forwarders, third-party logistics service providers and companies with logistics-intensive operations (Hylton \& Ross, 2018). These clusters also typically include the logistics operations of industrial firms such as the distribution centres of retailers and aftermarket parts suppliers (Sheffi, 2010; 2013). Despite the importance of transport and logistics clusters, there have been no studies investigating their potential contribution to the South African or NWP economies. Following the recommendations of Rivera et al. (2016) this study aims to identify the sectors that make up and that would benefit most from the transport and logistics clustering phenomenon. In addition, this study investigates the associated economy-wide effects of transport and logistics clusters on the NWP economy.

\section{LITERATURE REVIEW}

Transport and logistics clusters comprise transport services at the core of the cluster. Other sectors that make up the cluster include supporting industries (e.g. maintenance, legal, and information technology firms), critical institutions (e.g. manufacturing firms and wholesalers) and related industries (e.g. universities and other research institutions) (Sheffi, 2010; Lambourdiere et al., 2012). Transport and logistics clusters are classified in terms of scale (e.g. logistics villages in Germany, freight villages in Turkey, distribution parks in Japan); scope (e.g. urban distribution parks; regional or international clusters); by functions (e.g. free trade zones, bonded logistics parks or export processing zones); or by mode (e.g. airports, seaports, rail logistics parks, trucking logistics parks or hubs, or multi-modal parks) (Kasarda, 2008; Mangan et al., 2008; Sheffi, 2013b, 2016; Rivera et al., 2016). Some of the largest and most successful logistics clusters in the world are Memphis, Tennessee; Zaragoza, Spain; Rotterdam Port, Holland; Singapore Port area, Singapore; Panama Canal Zone, Panama; and Alliance in Fort Worth, Texas USA (Sheffi, 2013b). Schutjens and Stam (2003) found that business relationships between firms are localised in specific locations. Business relationships include cooperative relationships, sales relationships, supplier relationships, and outsourcing. Interaction between firms and institutions create supporting structures that link these interactions, and allows firms to prosper sustainably (Rivera et al., 2016).

Transport and logistics clusters can reduce transaction costs and improve the efficiency of both local and international trade. This is attributed to cooperation and collaboration between transport and logistics service providers located in close proximity (Cruijssen et al., 2010; Ergun et al., 2007; Sheffi, 2010; Van den Heuvel et al., 2015). Sheffi (2013a) postulates that the benefits associated with industrial cluster formation also accrue to members of transport and logistics clusters. Firms in transport and logistics clusters experience lower transport and transaction costs owing to economies of scale, economies of scope, economies of density and economies of frequency, which reduce the operational costs and enhance firm profitability (Rivera et al., 2016). Economies of scope 
in transport and logistics clusters are derived from the minimisation of the number of empty return trips for trucks by freight carriers through coordination of cluster members making use of the empty return trips (Sheffi, 2013b). Transport and logistics clusters generate economies of scale in freight transport owing to the high volumes of freight originating from and delivered to the cluster. These high volumes make it attractive for freight carriers to invest in larger vehicles, which in turn will reduce the unit cost of transporting freight for cluster members (Sheffi, 2013b). Economies of density relate to the coordination by freight carriers or third-party logistics operators to ensure that vehicles deliver a full load from the origin to the destination particularly for last mile deliveries (Sheffi, 2013a). Lastly, the large number of firms in a cluster increases demand for freight transport and increases the frequency of deliveries or shipments as a result of resulting in vehicle capacity being filled quicker owing (Sheffi, 2013a).

Transport and logistics clusters generate a wide range of jobs including manual jobs (sorting and hand-picking) (Chhetri et al., 2014), seasonal jobs during peak periods, which in turn create jobs for students and prospective candidates for full-time positions (Rivera et al., 2016). Professional jobs such as truck and train drivers, as well as ship and plane pilots, are created in transport and logistics clusters owing to the demand for technical expertise to operate various conveyance vehicles (Sheffi, 2012). Owing to the sophisticated IT applications used in supply chain management, transport and logistics clusters offer specialised IT-related jobs (Sheffi, 2013a). Transport and logistics clusters encourage the development of new and advanced logistics services such as network design, network planning, consulting and information technology services. Consequently, the transport and logistics industry is one of the major users of sophisticated information and communication technology. Such advancement creates innovative, new and highpaying specialised jobs. Lastly, there are several executive and managerial jobs in transport and logistics clusters (Sheffi, 2013b). Furthermore, owing to the on-job-training nature of logistics jobs, marginally educated workers can be promoted based on their experience in transport and logistics clusters (Rivera et al., 2016). Transport and logistics clusters enable firms to share assets such as warehouses, vehicle capacity and labour owing to the similarities in tasks performed in the cluster, for example, picking, sorting, loading, transporting, tracking, unloading and delivery (Rivera et al., 2016).

Transport and logistics clusters provide opportunities to enhance the value-added services at a lower cost. Distribution centres in these clusters create an opportunity for value to be added to products, for example, through tagging, packaging, preparing for retail display, and performing postponed operations before products move into the retail channels (Sheffi, 2010). Furthermore, clusters offer specialised services such as technology extension services, technology centres, export assistance, small business centres, and private sector services (Rada \& Van der Merwe, 1988). These services are provided by specialists such as designers, engineering consultants, accountants and lawyers, among others. In Taiwan clusters offer convenient services, such as bureaus for tariff duties to handle import as well as export affairs, logistic centres for customs-related issues and one-stop service shops that offer employment information (Qi \& Liu, 2015). In addition, the authorities also provide preferential loans, tax relief, and long-term financing, as well as other services, to cluster members. Cluster formation results in efficiencies by attracting infrastructure investment to the region and improve the efficiency of the transport networks (Khadaroo \& Seetanah, 2007). Transport and logistics clusters can facilitate the efficiencies of other sectors including tourism (Riviera et al., 2016). Improvements in transport derived from cluster formation result in improved service offering for the tourism sector in that affordable transport options improve accessibility to tourist destinations and increased accessibility. Transport and 
logistics clusters have been shown to improve accessibility to facilities including retail outlets, hospitals education facilities and tourism facilities (Hall \& Jacobs, 2012).

\section{STUDY SETTING}

South Africa, an emerging market, has been grappling to position itself as a key player in the global market. An analysis of the growth of South African supply or exports relative to international demand (imports) for the top 20 product sectors, reveals the structural weaknesses in South Africa's trade competitiveness. The top 20 export sectors contributed $59.2 \%$ of South Africa's total exports which amounted to US\$9.44billion in 2018 (Trade Map, 2019). Exports from South Africa are mainly primary sector products, which constitute a small proportion of world market share and are in low growth market segments. The largest export sectors (classified by volume) in 2018 were 1.) Platinum; 2.) Coal; 3.) Motor cars for the transport of persons and 4.) Gold (TradeMap, 2019).

The growth in supply of South African exports decreased for the most of the top 20 sectors. South Africa's platinum market share declined by 1.9\% despite world imports increasing at a rate of $5 \%$ (TradeMap, 2019). Similarly, South Africa's market share for gold, decreased $(-5.83 \%)$ despite world demand for this sector increased at a rate of $3 \%$ between 2014 and 2018. A large proportion of South Africa's exports in 2018 were classified as losers in growing markets (TradeMap, 2019). This means that despite these markets experiencing high positive growth rates, South Africa's share in world exports between 2014 and 2018 declined, implying loss of competitiveness for South African products. The North West province (NWP) of South Africa comprises four district municipalities which contain 18 local municipalities (Table 2). The economic composition of the NWP, the main producer of mineral resources, is not any different.

The NWP lies directly over the Rustenburg layered suite (RLS), a mineral ore deposit belt, which contains the world's largest mineral deposits of chrome, gold, vanadium, manganese and platinum group elements (North West Provincial Government, 2013; Bafokeng Platinum, 2012). Table 1 shows that the province's output is mainly concentrated in the mining sector. In 2018 the sector contributed $32 \%$ of the province's total output. Finance, insurance, real estate and business services (13\%); Wholesale and retail trade catering and accommodation (11\%); Manufacturing (10\%); and General government (10\%) sectors contributed smaller proportions of the total provincial output. The remaining five sectors contributed $24 \%$ to provincial output. Dependency on primary commodity exports makes the country and the province's macro-economic stability vulnerable to external shocks arising from fluctuations in global demand and exchange rate variations. It is therefore imperative to investigate alternative strategies for the NWP to explore in order to diversify economic activity and create new competitive advantages.

Table 1. NWP output per sector in 2018 (Data source: Quantec Easy Data, 2019)

\begin{tabular}{|l|c|c|}
\hline \multicolumn{1}{|c|}{ Sector } & $\begin{array}{c}\text { Output at basic prices } \\
\text { 2018 R million }\end{array}$ & $\begin{array}{c}\text { Share of total NWP } \\
\text { output in 2018 }\end{array}$ \\
\hline Agriculture, forestry and fishing & 17741,93 & $3,18 \%$ \\
\hline Mining and quarrying & 177624,305 & $31,87 \%$ \\
\hline Manufacturing & 56083,799 & $10,06 \%$ \\
\hline Electricity, gas and water & 18408,656 & $3,30 \%$ \\
\hline Construction & 23345,268 & $4,19 \%$ \\
\hline Wholesale and retail trade, catering and accommodation & 57947,014 & $10,40 \%$ \\
\hline Transport, storage and communication & 34812,848 & $6,25 \%$ \\
\hline Finance, insurance, real estate and business services & 73293,425 & $13,15 \%$ \\
\hline General government & 55054,686 & $9,88 \%$ \\
\hline Community, social and personal services & 42984,629 & $7,71 \%$ \\
\hline
\end{tabular}




\section{MATERIALS AND METHODS}

\section{Data}

A cross-sectional analysis was performed using two data sources in this study. Firstly, employment and output data for the transport and storage sub-sector was obtained from the Quantec Easy Data, RSA Standardised Regional Indicators database (2019). In this database, industries are classified under the Standard Industrial Classification (SIC) system into ten aggregated sectors, which include the aggregated transport, storage and communication sector. In particular, data for the transport and storage sub-sector per local municipality in the NWP was analysed.

Secondly, a social accounting matrix (SAM) for the NWP was used to identify the sectors that make up the transport and logistics sector and to calculate multipliers. A SAM captures the interlinkages and flow of funds between various entities in an economy. It comprises production accounts (also known as activities), commodities, factors of production institutions, households, firms and government (Robinson et al., 2001). A SAM depicts the circular flow of income that occurs in the economy (Round, 2003). The commodity accounts purchase finished goods from activities (producers) and the rest of the world (imports), while paying tariffs for imports (UNDP, 2012) The commodity accounts also sell commodities to the activity accounts (intermediate inputs) and to final demand (households, government, investment, and the rest of the world). In this study, it was more appropriate to use a region-specific or provincial SAM for the NWP, rather than a national SAM, to identify clusters that are specific to the province.

The 2006 SAM for the NWP was compiled by Conningarth Economists (2009). The 2006 SAM is the most recent available SAM for the NWP. This is because "data typically used to build SAMs include Input-Output (I-O) tables of the economy, national accounts, fiscal accounts, trade data, other balance-of-payments information and surveys providing information on the composition of household income and expenditures" (Debowicz et al., 2013: 2). I-O tables are published every five years while national income and product data are published on an annual basis (Robinson \& El-Said, 1997). As a result, SAMs are lagged owing to the reliance on I-O data (Harun et al., 2012).

\section{Methods}

Firstly, the transport sector's output and employment per local municipality were analysed in order to highlight the sector's spatial distribution in the province. In addition, growth rates were computed Secondly, a structural path analysis (SPA) and the power of pull (PoP) method were used to identify the sectors that make up the transport and logistics cluster in the NWP and to quantify the cluster's economy-wide effects relative to other clusters. This paper builds on previous work done on the identification of industrial clusters in the NWP (Pisa, 2014; Pisa et al., 2017). In-depth descriptions of the structural path analysis (SPA), and power of pull (PoP) methods have been described and published elsewhere (Pisa, 2014; Pisa et al., 2016). SPA shows how, in structural terms, an exogenous demand shock on the origin (transport) sector affects the destination sector (37 commodity sectors). An exogenous demand shock can be applied to export demand, government spending, or investment demand.

In this study a 10\% increase (shock) in the transport sector's exports, was imposed on intermediate demand for the other commodities in the NWP SAM. The shock was applied to the transport sector as the NWP SAM includes a transport sector and does not include a logistics sector. Based on the literature identifying the transport sector as the core sector in transport and logistics clusters (Sheffi, 2010), the transport sector was selected as the basis to identify the transport and logistics cluster in the NWP.

SPA computes path multipliers or quantifies the degree of amplification conferred throughout the elementary paths (inter-industry linkages) by adjacent circuits (i.e. an 
origin and destination account) (Defourny et al., 1984). The analysis traces the effect of a shock in the transport sector in the entire NWP economy (i.e. the 37 commodities in the NWP SAM) and produces path multipliers to all 37 commodities as destination sectors. In order to define the structure of the transport and logistics cluster, the destination sector was identified on account of the highest average path multiplier. Only the intermediate input demand generated was analysed without taking into consideration factors of production and institutions, as the focus of the analysis was identifying production sectors that make up the cluster. SimSIP SAM, a Microsoft Excel tool that utilises MATLAB (Parra \& Wodon, 2009) was used to analyse the NWP SAM and to identify the network of the transport and logistics cluster. This method, however, does not identify the cluster's economy-wide effects relative to other clusters. As previously mentioned, this study builds on previous work to identify multiple industry clusters for the NWP. Consequently, the power of pull (PoP) method was used to define the network effects of the transport and logistics cluster relative to other clusters in the NWP into a quantifiable criterion (Luo, 2013). The principle behind the PoP method is assessing a sector's ability to 'pull' itself and the activities and output of all other sectors. This also includes all sectors connected to it directly or indirectly throughout the economy. This ability of a sector is referred to as the PoP. By applying SPA and, subsequently, the PoP method to NWP SAM, the transport sector's PoP can be assessed and ranked to determine the economy-wide effects of the transport and logistics cluster in the NWP.

Lastly, the NWP SAM was used to compute simple economy-wide multipliers to illustrate the effects of the transport and logistics cluster on the economy of the NWP. Type I and type II multipliers were calculated to capture the downstream effects and upstream effects of the associated sectors in the cluster. Information embedded in the SAM table is used to calculate the cluster sectors' interlinkages (direct and indirect) as well as the cluster sectors' interlinkages with the rest of the sectors in the NWP SAM. In particular, the intermediate demand from the NWP SAM, is used. The total upstream effects of the cluster denote "the proportionate reduction in costs in an individual cluster sector caused by the lowering of intermediate input prices if the value added of all cluster sectors could be produced at zero cost" (Learmonth et al., 2003: 579).

If a sector in the transport and logistics cluster uses a high proportion of inputs from other sectors in the NWP economy, it will have high total upstream effects and vice versa. The downstream effect measures "the proportionate reduction in the output of a particular cluster caused as a result of reduced intermediate demand if the final demands for the output of all cluster sectors fell to zero" (Learmonth et al., 2003: 579). If a sector in the transport and logistics cluster has high intermediate sales to other sectors, then its downstream effects score will be high and vice versa.

\section{RESULTS DISCUSSIONS \\ Results}

In 2018 the NWP's output for the transport and storage sector ranked seventh relative to the other nine provinces (Quantec Easy Data, 2019). The NWP contributed 4.4\% (R2.8million) of the national output in transport and storage (Table 2: Quantec Easy Data, 2019). When compared to the other major economic hubs, the contributions to transport and storage output of Gauteng, KwaZulu Natal and Western Cape (32. 7\%; 23. $2 \%$ and $14.8 \%$ respectively), the NWP is lagging (Quantec Easy Data, 2019). In terms of spatial distribution of the transport and storage sector, output and employment data for the NWP were analysed according to local municipalities. Rustenburg and Madibeng local municipalities produced the highest proportions of transport and storage output in 2018 (21.35\% and $\mathbf{1 7 . 5 6 \%}$ respectively). Both local municipalities are in the Bojanala District 
Municipality (Table 2). City of Matlosana, located in the Dr Kenneth Kaunda District Municipality contributed the third largest proportion of transport and storage output. Mafikeng, located in the Ngaka Modiri Molema District Municipality, contributed the fourth largest output. The five lowest performing local municipalities in terms of output at basic prices in the transport and storage sector are not located in one single district municipality, but are dispersed over all four district municipalities that make up the NWP. Ratlou in the Ngaka Modiri Molema District Municipality, and Kgetlengrivier Local Municipality in Bojanala contributed $0.98 \%$ of transport and storage output in 2018.

Table 2. Spatial contributions to output, employment and profit in

transport, storage and communication in 2011 (Data source: Quantec Easy Data, 2019)

\begin{tabular}{|c|c|c|c|c|c|c|c|}
\hline \multirow[b]{2}{*}{$\begin{array}{c}\text { District } \\
\text { municipality }\end{array}$} & \multirow[b]{2}{*}{$\begin{array}{c}\text { Local } \\
\text { municipality }\end{array}$} & \multicolumn{3}{|c|}{ Output } & \multicolumn{3}{|c|}{ Employment } \\
\hline & & 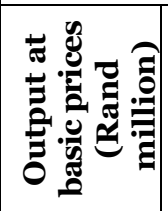 & 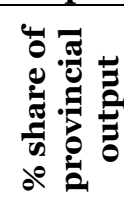 & 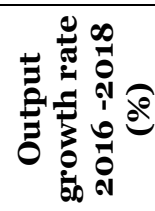 & 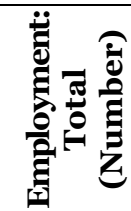 & 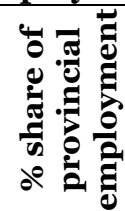 & 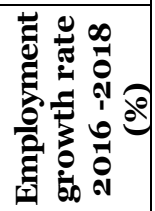 \\
\hline \multirow{2}{*}{ TOTAL } & South Africa & 638639,8 & & $4,48 \%$ & 605618 & & $\mathbf{0 , 4 9 \%}$ \\
\hline & North West & 28407,5 & $4,45 \%$ & $5,22 \%$ & 24903 & $4,11 \%$ & $\mathbf{0 , 2 8 \%}$ \\
\hline \multirow{5}{*}{ Bojanala } & Moretele & 1190,806 & $4,19 \%$ & $1,28 \%$ & 1211 & $4,86 \%$ & $-4,79 \%$ \\
\hline & Madibeng & 4988,55 & $17,56 \%$ & $5,74 \%$ & 4351 & $17,47 \%$ & $0,47 \%$ \\
\hline & Rusten & 6065,652 & $21,35 \%$ & $5,79 \%$ & 4698 & $18,87 \%$ & $1,24 \%$ \\
\hline & Kgetleng & 277,369 & $0,98 \%$ & $5,89 \%$ & 284 & $1,14 \%$ & $1,08 \%$ \\
\hline & Moses K & 1756,656 & $6,18 \%$ & $4,66 \%$ & 1632 & $6,55 \%$ & $-0,86 \%$ \\
\hline \multirow{5}{*}{$\begin{array}{c}\text { Ngaka } \\
\text { Modiri } \\
\text { Molema }\end{array}$} & Ratlou & 279,385 & $0,98 \%$ & $4,23 \%$ & 409 & $1,64 \%$ & $-0,24 \%$ \\
\hline & Tswaing & 540,699 & $1,90 \%$ & $5,25 \%$ & 577 & $2,32 \%$ & $-0,85 \%$ \\
\hline & Mafikeng & 2543,199 & $8,95 \%$ & $5,15 \%$ & 2163 & $8,69 \%$ & $-0,82 \%$ \\
\hline & Ditsobotla & 1616,935 & $5,69 \%$ & $5,26 \%$ & 1304 & $5,24 \%$ & $2,08 \%$ \\
\hline & Ramotshere Moiloa & 787,045 & $2,77 \%$ & $5,73 \%$ & 698 & $2,80 \%$ & $0,53 \%$ \\
\hline \multirow{5}{*}{$\begin{array}{c}\text { Dr Ruth } \\
\text { Segomotsi } \\
\text { Mompati }\end{array}$} & Kagisano/Molopo & 138,772 & $0,49 \%$ & $7,68 \%$ & 156 & $0,63 \%$ & $2,00 \%$ \\
\hline & Naledi & 592,198 & $2,08 \%$ & $4,84 \%$ & 579 & $2,33 \%$ & $-1,13 \%$ \\
\hline & Mamusa & 239,221 & $0,84 \%$ & $5,64 \%$ & 308 & $1,24 \%$ & $-0,85 \%$ \\
\hline & Greater Taung & 536,807 & $1,89 \%$ & $4,76 \%$ & 521 & $2,09 \%$ & $1,18 \%$ \\
\hline & Lekwa-Teemane & 545,177 & $1,92 \%$ & $4,11 \%$ & 520 & $2,09 \%$ & $0,06 \%$ \\
\hline \multirow{4}{*}{$\begin{array}{c}\text { Dr } \\
\text { Kenneth } \\
\text { Kaunda }\end{array}$} & Ventersdorp & 259,999 & $0,92 \%$ & $5,02 \%$ & 309 & $1,24 \%$ & $-1,36 \%$ \\
\hline & Tlokwe City Council & 1689,695 & $5,95 \%$ & $5,73 \%$ & 1549 & $6,22 \%$ & $1,19 \%$ \\
\hline & City of Matlosana & 3992,697 & $14,06 \%$ & $5,12 \%$ & 3218 & $12,92 \%$ & $1,30 \%$ \\
\hline & Maquassi Hills & 366,639 & $1,29 \%$ & $5,90 \%$ & 416 & $1,67 \%$ & $1,83 \%$ \\
\hline
\end{tabular}

Ventersdorp in the Dr Kenneth Kaunda District Municipality produced $0.92 \%$ of the NWP output in the sector. The Mamusa and Kagisano Local Municipalities in the Dr Segomotsi Mompati District Municipalities contributed the lowest output, that is $0.84 \%$ and $0.49 \%$ respectively. In terms of output growth rates in the period 2016 to 2018, the local municipalities with smaller transport and storage sectors showed high growth potential, namely Kagisano/Molopo (8\%), Maquassi Hills (6\%) and Kgetlengrivier (5.89\%). Rustenburg and Madibeng, the local municipalities with the largest transport and storage sectors, grew by $5.79 \%$ and $5.74 \%$ respectively. The majority of the NWP's local municipalities experienced growth above 5\%, except for Moretele, which experienced a growth rate of $1.28 \%$ in the sector (Table 2). The NWP contributed 24903 (4.1\%) jobs in the transport and storage sector. Similar trends to the locality of output can be observed with respect to the locality of employment in the NWP. 
The main employment centres for the transport and storage sector were Rustenburg, Madibeng, City of Matlosana, and Mafikeng. These four local municipalities contributed $57 \%$ of the transport and storage sector employment in the NWP. The lowest proportions of employment in the sector were in Ratlou, Ventersdorp, Mamusa, Kgetlengrivier and Kagisano/Molopo. The rates of employment growth were lower than output growth. The Ditsobotla and Kagisano/Molopo local municipalities experienced the highest sectoral employment growth rates between 2016 and 2018 (2.08\% and $2 \%$ respectively). Overall, the employment growth was low in the NWP with eight of the local municipalities experiencing negative employment growth.

The SPA results show the induced effects (elementary path or path multipliers) of a shock on the transport sector on all 37 commodity accounts or sectors that make up the NWP SAM as shown in Table 3. The results show the effects of the shock on all 37 sectors of the economy, and a clear cluster structure is not delineated. In order to identify the sectors that make up the transport and logistics cluster, averages of each sector's elementary paths were computed. The sector that yielded the highest average path multiplier was selected as the destination sector and was used to define the sector composition of the transport and logistics cluster for the NWP.

Table 3. Fixed origin from the transport sector to the communication sector: Structural path analysis (Data source: Conningarth Economists 2006 NWP SAM, 2009)

\begin{tabular}{|l|c|c|c|c|}
\hline $\begin{array}{c}\text { Elementary Paths Transmitting } \\
\text { Global Influence of o,o515994 }\end{array}$ & $\begin{array}{c}\text { Direct } \\
\text { Influence }\end{array}$ & $\begin{array}{c}\text { Path } \\
\text { Multiplier }\end{array}$ & $\begin{array}{c}\text { Total } \\
\text { Influence }\end{array}$ & $\begin{array}{c}\text { Total/Global } \\
\text { Influence (\%) }\end{array}$ \\
\hline Transport/Communication & 0,0165 & 1,3397 & 0,0221 & 42,74 \\
\hline Transport/Trade/Communication & 0,0039 & 1,4576 & 0,0057 & 10,98 \\
\hline Transport/Real Estate/Communication & 0,0035 & 1,5722 & 0,0054 & 10,56 \\
\hline Transport/Trade/Communication & 0,0013 & 1,4576 & 0,0019 & 3,69 \\
\hline Transport/Real Estate/Trade/Communication & 0,0006 & 1,6669 & 0,0010 & 1,97 \\
\hline $\begin{array}{l}\text { Transport/Community, Social and Personal } \\
\text { Services/Communication }\end{array}$ & 0,0005 & 1,3848 & 0,0006 & 1,25 \\
\hline Transport/Communication & 0,0004 & 1,4798 & 0,0006 & 1,22 \\
\hline $\begin{array}{l}\text { Transport/Chemicals \& Chemical } \\
\text { Products (including(incl Plastic } \\
\text { Products)/Trade/Communication }\end{array}$ & 0,0003 & 1,6522 & 0,0004 & 0,84 \\
\hline Transport/Communication & 0,0003 & 1,4646 & 0,0004 & 0,84 \\
\hline Transport/Communication & 0,0003 & 1,4732 & 0,0004 & 0,82 \\
\hline Transport/Communication & 0,0003 & 1,4847 & 0,0004 & 0,80 \\
\hline $\begin{array}{l}\text { Transport/Business } \\
\text { Services/Communication }\end{array}$ & 0,0003 & 1,3742 & 0,0004 & 0,76 \\
\hline $\begin{array}{l}\text { Transport/Trade/Real } \\
\text { Estate/Communication }\end{array}$ & 0,0002 & 1,6669 & 0,0003 & 0,60 \\
\hline Transport/Communication & 0,0002 & 1,4668 & 0,0003 & 0,51 \\
\hline Transport/Real Estate/Communication & 0,0002 & 1,6710 & 0,0003 & 0,50 \\
\hline
\end{tabular}

The communication sector yielded the highest average path multiplier and, as a result, was identified as the destination sector in the fixed origin analysis of SPA. This implies that highest degree of amplification of the effects of a stimulus in the transport sector to the rest of the NWP economy can be conferred through the communication sector. Table 3 shows the SPA results of effects of a stimulus on the transport and logistics cluster (as the origin sector) on intermediate demand for the other commodities. SPA calculates the direct influence, path multiplier, total influence and total/ global influence (as a percentage) for each elementary path. The direct influence 
isolates the individual paths through which the influence of the $10 \%$ increase in transport export follows effects in the communication sector, if all other things remain constant (ceteris paribus). The global influence is the sum of induced and feedback effects resulting from underlying interlinkages between sectors (Defourny et al., 1984). A 10\% increase in transport exports yields a $5 \%$ increase in the communication sector (0.052; column 3; Table 3). It is evident that there are several direct paths between the transport and the communication sectors as there are several direct paths linking the two sectors without any other poles. Of the global influence (0.052) of a shock on transport, $47 \%$ is conferred if the communication is exercised directly while the remainder is exercised through indirect paths. The elementary path with highest direct effect accounts for $42.74 \%$ of the global influence. The communication sector is the most important sector in the cluster as it appeared the most times (15 times) in the elementary paths of the cluster.

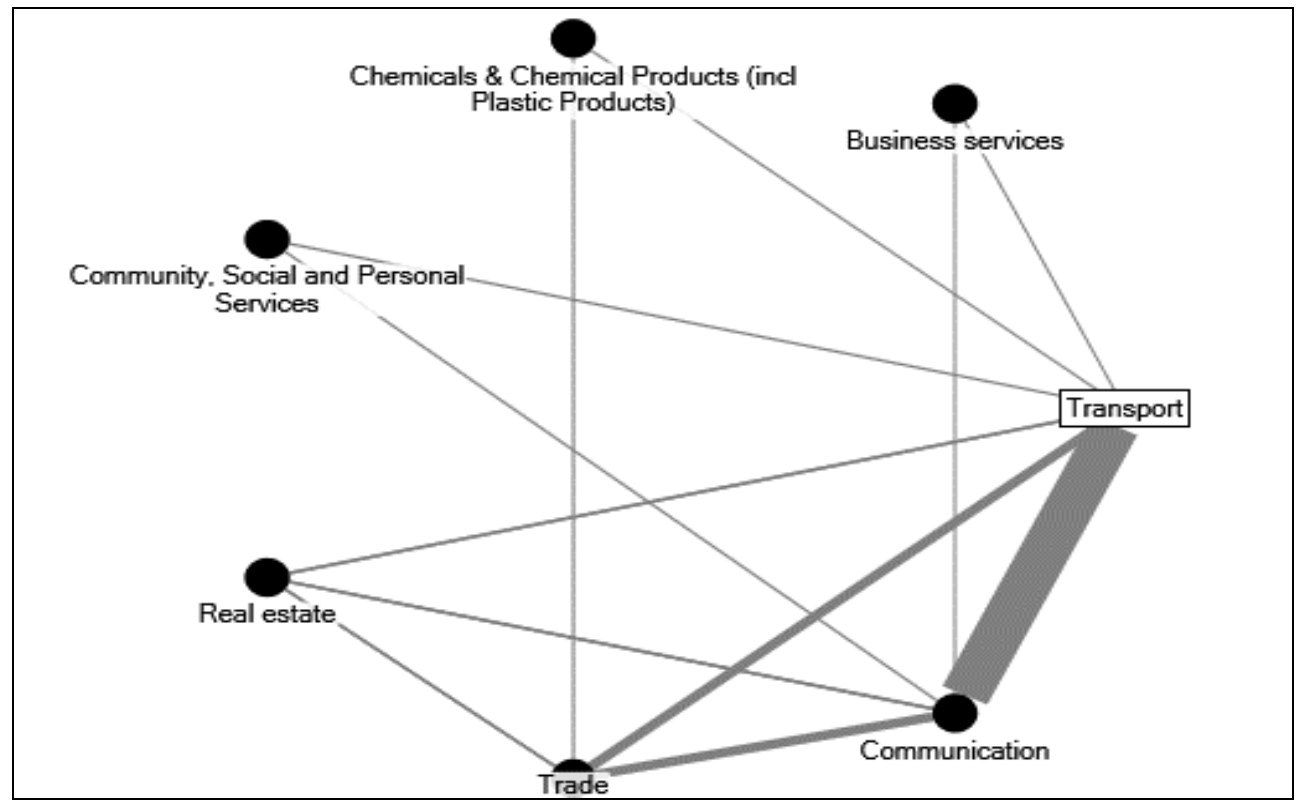

Figure 1. Transport and logistics cluster: Structural path through the communication sector in the NWP (Source: Conningarth Economists 2006 NWP SAM, 2009)

Figure 1 shows the sectors that make up the transport sector. The transport and logistics cluster comprises seven sectors, namely: i) Transport ii) Trade iii) Communication iv) real estate, v.) Community, social and personal services, vi) Chemicals and chemical products, and vii) Business services. The relationships between the cluster sectors or inter-industry linkages between sectors are shown by lines connecting the sectors. The absence of a line between sectors shows that no interlinkages exist between those sectors. The thickness of the line represents the relative volume of flow or strength of the interlinkages along the path. The thickest lines represent the greatest volume of flow, while the thin lines represent the least relative volume of interlinkages in the cluster. As shown in Table 3 the communication sector is the most important sector in the cluster as the highest volume of interlinkages exist (thickest line; Figure 1) between the transport and communication sectors. The transport sector also exhibits strong links with trade and real estate. Other, less important linkages in terms of magnitude are between trade and communication as well as between real estate and communication. Although six of the 37 
sectors in the NWP benefit from induced demand increases in the transport sector export, the cluster generates a cumulative effect of 78.09\% in the economy (Table 3).

Table 4 shows the transport sector results of the PoP analysis, namely: i) the PoP values and rankings, and ii) the sector's direct measures in the NWP SAM. The direct measures are a measure of the contributions of the transport sector to intermediate inputs, commodity output and value added in the NWP SAM. The direct measures show the actual size of the sector and these differ from the results of the PoP, which trace the induced effect of a shock on the sector. The PoP of the transport and logistics cluster ranked $14^{\text {th }}$ out of 37 potential commodities clusters (fifth by intermediate input; sixth by commodity output and eighth by value added) compared to the other 36 commodities making up the NWP economy. This implies that although the sector is relatively large, as shown by the intermediate input, commodity output and valueadded rankings, the efficacy of its influence on other sectors is moderate.

Table 4. NWP's transport and logistics cluster rankings according (Data source: Conningarth Economists 2006 NWP SAM, 2009 and PoP results)

\begin{tabular}{|c|c|c|c|c|c|c|c|c|}
\hline \multirow{2}{*}{ Sector } & \multicolumn{2}{|c|}{ PoP } & \multicolumn{2}{c|}{ Intermediate Input (SAM) } & \multicolumn{2}{c|}{ Commodity Output (SAM) } & \multicolumn{2}{c|}{ Value Added (SAM) } \\
\cline { 2 - 9 } & Value & Rank & Value (Rm) & Rank & Value (Rm) & Rank & Value (Rm) & Rank \\
\hline Transport & 1,911 & 14 & 6803 & 5 & 11789 & 6 & 4985 & 8 \\
\hline
\end{tabular}

The results of the multiplier analysis for the transport and logistics cluster are presented in Figure 2. The figure shows the multiplier values for the sectors that make up the transport and logistics cluster for the NWP. The results presented in this section are similar to a previous analysis identifying industrial clusters in the NWP, as the sectors that make up the economy are the same (Pisa, 2014). As a result, the sectors that make up the transport and logistics cluster are similar but not identical to any of the clusters identified in the study of Pisa (2014). Figure 2 depicts the transport and logistics cluster's interlinkages with the rest of the sectors in the NWP.

The figure shows, for each sector in the cluster, the size of the sector (according to the 2009 NWP SAM - given by size of the bubble), the downstream effects (y-axis) and the upstream effects (x-axis). The scale for the upstream and downstream effects lies between $\mathrm{o}$ and 100 percent. The scale or size of the sector does not influence the levels of upstream and downstream effects. The highest relative backward and forward linkages (indicative of a strong cluster) are associated with sectors that lie in the top right corner of the diagram. Such a cluster is indicative of a set of sectors that have high interlinkages, are highly reliant on each other's value added and final demands, and is thus illustrative of a highly integrated cluster. In terms of scale the Trade and Community, social and personal services (CSPS) are the largest sectors in the cluster. The Business services (92\%) and Chemicals and chemical products (chemicals etc; 75\%) sectors use a high proportion of inputs from other sectors in the NWP economy that is, these sectors have high upstream effects. The TTrade sector has the highest downstream effects (85\%) indicating that the sector has high intermediate sales to other sectors. The CSPS sector has low downstream effects and relatively high upstream effects. The Real estate sector is characterised by high downstream effects and low upstream effects. The Transport and Communication sectors have low upstream as well as low upstream effects. This cluster is relatively integrated and has potential to integrate more with cluster formation.

\section{Discussion}

The aim of this study was to identify the sectors that make up and that would benefit most from the transport and logistics clustering phenomenon. This study also investigated the associated economy-wide effects of transport and logistics clusters on the 
NWP economy. This is the first study, to our knowledge, to investigate the composition of transport and logistics clusters and their associated effects on the economy of the NWP in South Africa. This was achieved by analysing the output and employment data for the NWP for 2018 in order to determine the locality of the sector's economic activity in the province. The SPA and PoP methods were then applied to a provincial SAM for the NWP to identify the sectors that make up the transport and logistics cluster and to quantify the cluster's economy-wide effects relative to other clusters in the NWP.

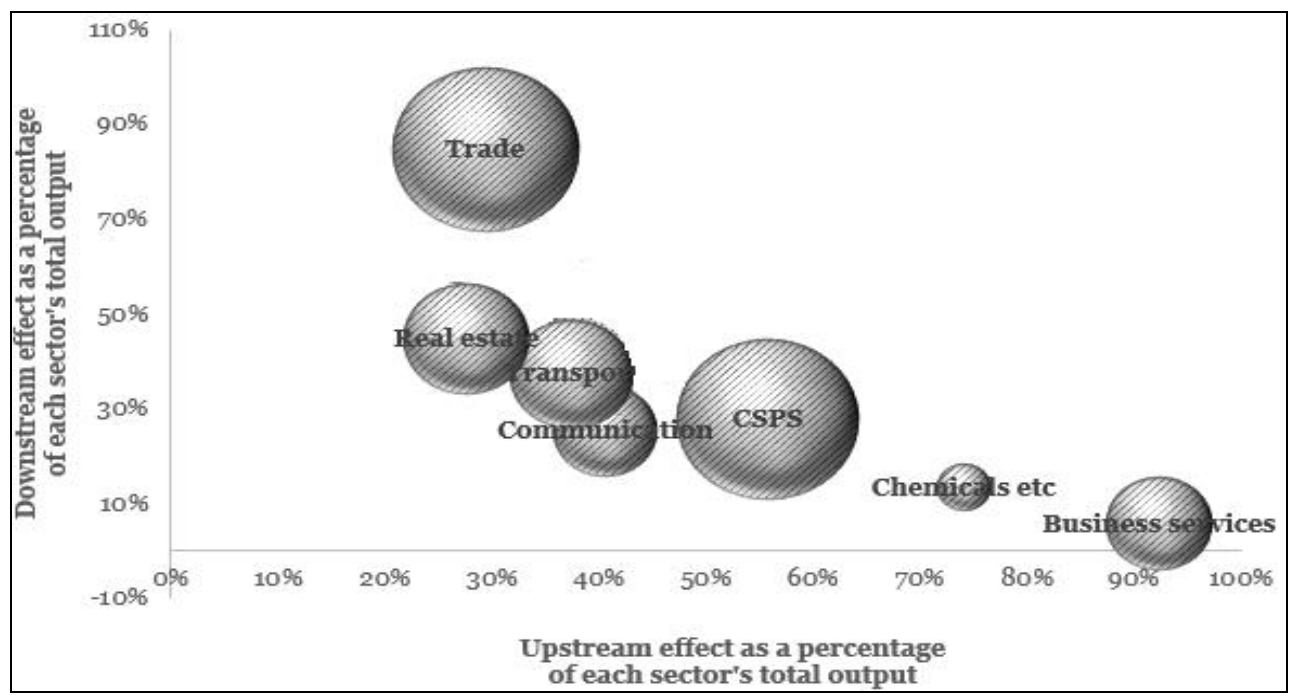

Figure 2. Upstream and downstream linkage effects of the NWP transport and logistics cluster and related sectors (Source: Conningarth Economists 2006 NWP SAM, 2009)

Thirdly, type I and type II multipliers were computed to determine the associated effects of the transport and logistics cluster on the economy of the NWP. The analysis of the province's comparative advantage showed that the NWP's output for the transport and storage sector ranked seventh relative to the other nine provinces and contributed $4.4 \%$ (R2.8million) of the national output in the transport sector. The results revealed that the province's comparative advantage in the transport and storage sector lies in Rustenburg and Madibeng local municipalities located in the Bojanala District Municipality; City of Matlosana, located in the Dr Kenneth Kaunda District Municipality; and Mafikeng, situated in the Ngaka Modiri Molema. This suggests that the locality of clusters is likely to be in these local municipalities. Barkley and Henry (2001) stated that "a prerequisite to developing a cluster is the identification of regional competitive advantage based on labour force characteristics, unique regional attributes, availability and quality of public and private infrastructure, and proximity to input and product markets".

Future research should investigate the levels of collaboration between firms in the transport and logistics cluster to determine if the cluster is active or latent. Latent clusters exist where critical mass for cluster formation exists, but there is little or no interaction and information flow between firms (Enright, 2003). This means that firms are not aware of the potential benefits of strengthening existing interlinkages or are not willing to engage in collaborative cooperation. An analysis of the NWP's growth rates in output and employment in the transport and storage sector showed that the municipalities with the largest contributions to transport and storage output, Rustenburg and Madibeng, recorded the highest growth rates of $5.79 \%$ and $5.74 \%$ respectively. However, the rates of 
employment growth were lower than output growth with the highest growth rate of $2 \%$ experienced in the municipalities with smaller transport and storage sector contributions to output, namely Ditsobotla and Kagisano/Molopo local municipalities. Hylton and Ross (2018) found associations between high growth rates and and the number of logistics firms in the cluster. This implies that transport and logistics clusters attract more firms to locate and operate in the region, thus increasing sectoral output and employment.

With respect to identifying the sectors that make up the transport and logistics cluster, the averages of the path multipliers were computed. Key strengths of this study include the robust methodology in determining the cluster used in this current study as the main independent variable (detailed methodology described elsewhere, Pisa, 2014; Pisa et al., 2017). The main advantage of using SPA in industrial cluster identification is its ability to isolate direct and indirect components and the various paths through which income flows (Defourny et al., 1984). However, SPA has the following shortcomings: Cross-sectional data, namely the NWP SAM, output and employment data for transport and storage sector, were used to identify sectors that make up the transport and logistics cluster. This data is dated and lagged in the case of the SAM, increasing the likelihood of identifying old trends and therefore clusters that may be declining. In addition, cross- sectional data can only test associations, and causality cannot be inferred. Baydar et al. (2019) found that, despite significant efforts by the government to support logistics clusters, Turkish freight villages were significantly smaller and were under-utilized owing to the fact that these spatial clusters of logistics firms were surrounded by residential firms rather than by supporting industries that would benefit from the cluster. It is therefore important for future research to determine the composition of firms in the areas identified to have a high concentration of transport and storage economic activity, namely Rustenburg, Madibeng, City of Matlosana and Mafikeng, to ensure that the cluster can facilitate coordination and collaboration in the flow of goods. The elementary paths between the transport and communication sectors yielded the highest average path multiplier and were used to define the composition of the transport and logistics cluster. The analysis revealed that the transport and logistics cluster comprises seven sectors, namely: i) Transport, ii) trade, iii) Communication, iv) Real estate, v) Community, social and personal services, vi) Chemicals and chemical products, and vii) Business services. The communication sector is the most important sector in the cluster as the highest volume of interlinkages exists between the transport and communication sectors. The transport sector also exhibits strong links with trade and real estate.

The results of the PoP analysis showed that the PoP of the transport and logistics cluster ranked $14^{\text {th }}$ (fifth by intermediate input; sixth by commodity output and eighth by value added) in the NWP economy. This implies that although the sector is relatively large, as shown by the intermediate input, commodity output and value-added rankings, the efficacy of its influence on other sectors is moderate. The multiplier analysis for the transport and logistics cluster revealed that the transport and logistics cluster comprises sectors with high upstream (business services and chemicals, etc.) and downstream effects (trade). Overall, this cluster is relatively integrated and has the potential to integrate more with cluster formation. The assumed benefits of logistics clusters have also been tested and were found to be positive in other studies. Duschl et al. (2015) and Rivera et al. (2014) found higher employment rates in logistics clusters compared to that in non-clusters.

Hylton and Ross (2018) found mild effects of logistics clustering on growth. Furthermore, it has been shown that spatial clusters have a strong positve association with transport infrastructure investment (Yu et al., 2012). It is therefore expected that the transport and logistics clusters will attract investment in infrastructure, which will in turn improve distrubution networks, reduce transport and transaction costs, and improve business competitiveness. A closer examination of relationships between the cluster sectors 
suggests that the composition of sectors in the identified transport and logistics cluster resembles the characteristics of transport and logistics clusters outlined in the literature.

The cluster comprises the business services sector, which has interlinkages with the transport and communication sectors. In addition to the interlinkages with the transport sector, the real estate sector has interlinkages with the trade and communication sectors. The community, social and personal services sector has interlinkages with the communication and transport sectors, while the chemicals and chemical products sector has linkages with transport and trade. This could be indicative of the existence of thirdparty logistics service providers or integrated logistics service providers in the provincial economy and in the cluster specifically. These findings are consistent with recent studies on the identification of logistics clusters that have found the cluster composition to include logistics service providers (Rivera et al. 2014; Van den Heuvel et al., 2015), supporting industries (such as insurance and finance), customers (e.g., manufacturers) and, in this present study, the chemicals and chemical products sector (Sheffi, 2010). These clusters are classified as vertical clusters and comprise sectors up and down the value chain (Sheffi, 2010). The NWP transport and logistics cluster is characteristic of a freight village, as the province is landlocked and does not have a major airport.

Freight villages offer support services to facilitate the flow of goods using intermodal solutions and infrastructure (Baydar et al., 2019). The two outcomes presented in the current analysis namely; output and employment growth assocaiate with transport and logistics clusters are known independent predictors for tourism industry in South Africa. Furthermore, 12 key transport and logistics factors have been identified and discussed in depth by Litman (2008). In summary these included: i.) the cost of travel ii.) the level of connectivity of the network iii.) the levels of intergation of the different tranpsort modes iv.) the number of transport modes available and the availabiltiy of travel substitutes (Litman, 2008; Van Truong \& Shimizu, 2017). Currie and Falconer (2014) found improvements in accessibility, (which are derived from improvements in transport and logistics) to improve the competitiveness in the tourism sector. Transport and logistics optimisation was found to improve tourism networks (Frias, et al., 2015) tourism flows (Pagliara et al., 2015) and costs associated with travel, accomodation and services at the tourist destinations (Bimonte et al., 2015; Van Truong \& Shimizu, 2017). In the context of South Africa, this implies that transport and logistics cluster optimisation has a knock on effect on various industries including tourism as shown elsewhere.

\section{CONCLUSION}

To our knowledge, this is the first analysis to explore the association between transport and logistics clusters with economy-wide effects in the NWP of South Africa. A methodological framework, to define the composition of transport and logistics clusters and to test the associated effects on the NWP economy, is demonstrated in this study. Positive associations exist between the transport and logistics cluster and multipliers (upstream and downstream effects) in various sectors within the NWP. Additionally, the sectors in the cluster are relatively integrated and have high interlinkages. The cluster has potential to integrate once the cluster is strengthened. This study offers a unique econometric approach to identify and quantify the effects of transport and logistics clusters on regional competitiveness, and provides practitioners and policy makers with insights into alternative strategies to enhance regional competitiveness and growth.

However, the results should be interpreted with caution as macro-level (crosssectional) data used in this analysis do not reveal micro-relationships or provide insights into whether the clusters are latent or active. It is therefore important for future research to investigate the levels of existing cooperation between firms in the cluster. 


\section{REFERENCES}

Ahmad, S., Kaliappan, S., \& Ismail, N. (2017). Determinants of service exports in selected developing Asian countries. International Journal of Business and Society, 18(1), 113-132.

Awokuse, T. O. (2008). Trade openness and economic growth: Is growth export-led or import-led? Applied Economics, 40, 161-173.

Balassa, B. (1978). Exports and economic growth: Further evidence, Journal of Development Economics, 5(2): $181-189$.

Barkley, D.L., \& Henry, M.S. (2001). Advantages and disadvantages of targeting industry clusters. Regional Economic Development Research Laboratory research report. South Carolina: University of Clemson.

Baydar, A.M., Sural, H. \& Çelik, M. (2019). Potential effects of logistics clusters: The case of Turkish Freight Villages. Journal of Cleaner Production, 233: 399-411

Bimonte, S., Ferrini, S., \& Grilli, G. (2015). Transport Infrastructures, environment impacts and tourists' welfare: A choice experiment to elicit tourist preferences in Siena-Italy. Journal of Environmental Planning and Management, doi:10.1080/09640568.2015.1044746

Chhetri, P., Butcher, T., \& Corbitt, B. (2014). Characterising spatial logistics employment clusters. International Journal of Physical Distribution \& Logistics Management, 44 (3): 221-241.

Conningarth Economists. (2009). Provincial social accounting matrix for the North-West Province. Report prepared for the North-West Province Government.

Cruijssen, F., Dullaert, W., \& Fleuren, H. (2007). Horizontal cooperation in transport and logistics: A literature review. Transportation Journal, 46(3), 22-39.

Cruijssen, F., Dullaert, W. \& Joro, T. (2010). Freight transportation efficiency through horizontal cooperation in Flanders. International Journal of Logistics Research and Applications, 13(3): 161-178.

Currie, C. \& Falconer, P. (2014). Maintaining sustainable island destinations in Scotland: The role of the transport-tourism relationship. Journal of Destination Marketing \& Management, 3 (3): 162-72. doi:10.1016/j.jdmm.2013.10.005.

Debowicz, D., Dorosh, P., Haider, H.S. \& Robinson, S. (2013). A disaggregated and macro-consistent social accounting matrix for Pakistan. Journal of Economic Structures, 2(4): 1-30.

Defourny, J., \& Thorbecke, E. (1984). Structural path analysis and multiplier decomposition within a social accounting matrix framework. The Economic Journal, 94: 111 - 136.

Duschl, M., Scholl, T., Brenner, T., Luxen, D., \& Raschke, F. (2015). Industry-specific firm growth and agglomeration. Regional Studies, 49, 1822-1839. doi:10.1080/00343404.2013. 861059.

Enright, M. J. (2003). Regional clusters: what we know and what we should know. (In Bröcker, J., Dohse, D. \& Soltwedel, R. eds. Innovation clusters and interregional competition. Berlin; London: Springer. p409).

Ergun, O., Kuyzu, G., \& Savelsbergh, M. (2007). Reducing truckload transportation costs through collaboration. Transportation Science, 41(2): 130-161. doi/abs/10.1287/trsc.1060.0169

Frias, A., Cabral, J. \& Costa, Á. (2015). Logistic optimization in tourism networks. Conference: 55th European Regional Science Association Congress, Lisbon, Portugal (25-28 August 2015), doi: 10.13140/RG.2.1.1617.0967.

Hall, P.V. \& Jacobs, W. (2012). Why are maritime ports (still) urban, and why should policy makers care? Maritime Policy \& Management, 39(2):189-206.

Harun, M., Zakariah, A.R. \& Azali. M. (2012). Constructing a social accounting matrix framework to analyse the effects of public expenditure on income distribution in Malaysia. Jurnal Ekonomi Malaysia, 46(2): 63 - 83.

Hylton, P., \& Ross, C.L. (2018). Agglomeration Economies' Influence on Logistics Clusters' Growth and Competitiveness. Regional Studies 52 (3): 350- 61.

Kagawa, S., Kondo, Y., Nansai, K. \& Suh, S. (2010). Detecting energy clusters from the automobile supply chain: spectral clustering approach. The 18th International Input-Output Conference, 20-25 June, 2010, University of Sydney.

Kasarda, J. D. (2008). Aerotropolis ambitions. Business Outlook India.

Khadaroo, J. \& Seetanah, B. (2007). Transport infrastructure and tourism development. Annals of Tourism Research, 34(4):1021-1032, doi: 10.1016/j.annals.2007.05.010.

Lambourdiere, E., Corbin, E., \& Savage, C. J. (2012). Global supply chains, logistics clusters and economic growth: What could it mean to Caribbean territories? Proceedings of the Conference on the Economy, University of the West Indies.

Learmonth, D., Munro, A. \& Swales, K.J. (2003). Multi-sectoral cluster modelling: the evaluation of Scottish enterprise cluster policy. European Planning Studies, 11(5):567-584.

Litman, T. (2008). Evaluating accessibility for transportation planning. http://trid.trb.org/view.aspx?id=859513.

Luo, J. (2013). Which industries to bail out first in economic recession? Ranking US industrial sectors by the power ofpowerof-pull. Economic Systems Research, 25(2), 1-23.

Mangan, J., Lalwani, C. \& Fynes, B. (2008). Port-centric logistics. The International Journal of Logistics Management, 19(1): 29-41. doi.org/10.1108/09574090810872587.

Meintjes, C.J. (2001). Guidelines to regional socio-economic analysis. Development Bank of Southern Africa. Development Information Business Unit. Development Paper 145. ISBN 1-919692-58-4.

Ngandu, S., Garcia, A.H. \& Arndt, C. (2010). The economic influence of infrastructural expenditure in South Africa: a multiplier and structural path analysis. Development Policy Research Unit, Employment Promotion Programme and Trade \& Industrial Policy Strategies Conference. 27-29 October 2010. Johannesburg: South Africa.

Nguyen Van Truonga, N. \& Shimizu, M. (2016). The effect of transportation on tourism promotion: Literature review on application of the Computable General Equilibrium (CGE) Model. World Conference on Transport Research - WCTR 2016 Shanghai. 10-15 July 2016. 
Pagliara, F., La Pietra, A., Gomez, J. \& Vassallo, J.M. (2015). High speed rail and the tourism market: Evidence from the Madrid case study. Transport Policy, 37: 187-94. doi:10.1016/j.tranpol.2014.10.015

Parra, J. C. \& Wodon, Q. (2009). SimSIP_SAM: A tool for the analysis of Input - Output tables and Social Accounting Matrices. Washington DC: World Bank.

Pisa, N.M. (2014). Identifying industrial clusters for competitiveness: Policy implications for economic development in the Northwest province of South Africa. PhD thesis, Northwest University, South Africa.

Pisa, N.M., Viviers, W. \& Rossouw, R. (2017). Exploring realistic export opportunities for industrial clusters in the North West Province of South Africa using the decision support model. South African Journal of Economics. 48(3): 386-404.

Pisa, N.M., Viviers, W. \& Rossouw, R. (2016). Enhancing Industrial Cluster Formation Through the Realistic Export Opportunities of the TRADE-DSM. South African Journal of Economics, 85(3):1-19.

Prause, G. (2010). Logistics related entrepreneurship and regional development: An empirical study. In J. Kramer, G. Prause, \& J. Sepp, Baltic business and socio-economic development. Berlin: Berliner Wissenschafts- Verlag.

Qi, Y., \& Liu, S. (2015). Integrated model of cluster supply chain and logistics parks. Applied Mechanics and Materials, 69(7), 508-511.

Rada, J., \& Van Der Merwe. S. (1988). Servitization of business: adding value by adding service. European Management Journal, 6(4), 314-320.

Rivera, L., Gligor, D., \& Sheffi, Y. (2016). The benefits of logistics clustering. International Journal of Physical Distribution and Logistics Management, 46(3), 242- 268.

Rivera, L., Sheffi, Y., \& Welsch, R. (2014). Logistics clusters in the US. Transportation Research Part A: Policy and Practice, 59, 222-238.

Roberts, D. (2005). The role of households in sustaining rural economies: a structural path analysis. European Review of Agricultural Economics, 32: 393-420.

Robinson, S. \& El-Said, M. (1997). Estimating a social accounting matrix using entropy difference methods. International Food Policy Research Institute: Washington, DC.

Robinson, S., Cattaneo, A. \& El-Sai., M. (2001). Updating and estimating a Social Accounting Matrix using cross entropy methods. Economic Systems Research, 13(1): 47-64.

Round, J. (2003). Social accounting matrices and SAM-based multiplier analysis. (In da Silva Pereira, L. A. \& Bourguignon, F. eds. Techniques for evaluating the poverty effects of economic policies. World Bank and Oxford University Press).

Sandberg, E. (2007). Logistics collaboration in supply chains: Practice vs theory. The International Journal of Logistics Management, 18(2), 274-293.

Schutjens, V., \& Stam, E. (2003). The Evolution and Nature of Young Firm Networks: A Longitudinal Perspective, 21(2):115-134.

Sheffi, Y. (2010). Logistics intensive clusters. ÉPOCA, 20(1-2), 11-17.

Sheffi, Y. (2012). Logistics Clusters: Delivering Value and Driving Growth. Cambridge, MA: MIT press.

Sheffi, Y. (2013a). Driving growth and employment through logistics. MIT Sloan Management Review, 54(1).

Sheffi, Y. (2013b). Logistics-intensive clusters: Global competitiveness and regional growth. In J. Bookbinder, Handbook of Global Logistics (pp. 463-500). Denver, CO.: Springer Science+Business Media.

Sheffi, Y. (August, 2016). Mitigating the High Risk of Low Cost Items. Inside Supply Chain Management: 28-31.

Van den Heuvel, F. P., Van Donselaar, K. H., De Langen, P. W., \& Fransoo, J. C. (2015). Co-location synergies: Specialized versus diverse logistics concentration areas. Tijdschrift voor Economische en Sociale Geografie, 107, 331-346, doi: 10.1111/ tesg.12152.

Van den Heuvel, F.P., De Langen, P.W., Van Donselaar, K.H., \& Fransoo, J.C. (2012). Proximity matters: synergies through co-location of logistics establishments. Beta Working Paper Series. No. 380.

Van Dijk, M. P. \& Sverrisson, A. (2003). Enterprise clusters in developing countries: mechanisms of transition and stagnation. Entrepreneurship and Regional Development, 15: 183-206.

Von Truong N. \& Shimizu, T., (2017). The effect of transportation on tourism promotion: Literature review on application of the Computable General Equilibrium (CGE) Model. Transportation Research Procedia, 25: 3096-3115.

Yu, N., De Jong, M., Storm, S., \& Mi, J. (2012). Transport infrastructure, spatial clusters and regional economic growth in China. Transport Reviews, 32(1), 3-28.

Yuan, X. M., Low, J. W., \& Tang, L. (2010). Roles of the airport and logistics services on the economic outcomes of an air cargo supply chain. International Journal of Production Economics, 127, 215-225.

Zhou, X., Wang, Z., \& Sun, H. (2015). Research on the interaction between resource logistics industrial cluster and regional economics. Advanced Materials Research, 1073, 2372-2376.

*** Bafokeng Platinum. (2012). Integrated annual report. http://www.bafokengplatinum.co.za/im/files/ reports/2012/RBPlat-AR-2012-reserves-resources.pdf.

*** North West Provincial Government. (2013). Overview. http://www.nwpg.gov.za/Overview.asp.

*** RSA Standardised Regional Indicators database (2019). South Africa Economic Indicator. https://www.easydata.co.za/

*** TradeMap. (2019). Trade indicators. www.trademap.org.

*** Quantec Easydata. (2019). Regional indicators. www.easydata.co.za.

*** United Nations Development Programme (UNDP). Annual Report 2011-2012. https://www.undp.org/content/ undp/en/home/librarypage/corporate/annual-report-2011-2012--the-sustainable-future-we-want.html.

Submitted:

01.07.2019
Revised:

06.12.2019
Accepted and published online 09.12.2019 